\title{
PO(ST)GRANICZNE NARRACJE MIEJSKIE. LITERACKIE RE-KONSTRUKCJE ŻYDOWSKIEGO SZCZECINA ${ }^{1}$
}

\author{
PAWE€ WOLSKI ${ }^{2}$ \\ (Szczecin)
}

\begin{abstract}
Słowa kluczowe: urban studies, literatura Zagłady, literatura żydowska
\end{abstract}
Keywords: urban studies, Holocaust literature, Jewish studies

\begin{abstract}
Abstrakt: Paweł Wolski, PO(ST)GRANICZNE NARRACJE MIEJSKIE. LITERACKIE RE-KONSTRUKCJE ŻYDOWSKIEGO SZCZECINA. „PORÓWNANIA” 11, 2012, Vol. XI, s. 291-300, ISSN 1733-165X. Żydowska tożsamość powojennego Szczecina rysuje się w sposób charakterystyczny dla obrazu żydowskiej społeczności w całej Polsce: jest naznaczona piętnem nie-obecności. Ta nie-obecność przedstawia się jednak w sposób ciekawszy i bardziej złożony, niż mogłoby to wynikać z tej nieco zbanalizowanej obserwacji o traumatycznej pustce. Żydowski Szczecin $\mathrm{w}$ powojennej literaturze funkcjonuje na zasadzie znaczącego, signifiant żydowskiego miasta, opierającego się na znacznikach zaczerpniętych z innych miejskich struktur - Warszawy, Kielc itd. Niniejszy artykuł omawia przejściowość literackiego Szczecina, jego ulotną tożsamość wyłaniającą się z prozy Anny Frajlich, Ingi Iwasiów, Alana Sasinowskiego, szczególnie zaś z fragmentu tekstu Taube Kron, która opisując powojenny Szczecin wyraźnie odwołuje się do innych miejsc pamięci: warszawskiego getta, pogromowych Kielc, żydowskiego Lwowa. W artykule postawiona zostaje teza, że „podwójna nieobecność” (tożsamości żydowskiej i miejskiej) jest wprawdzie emblematyczna dla powojennej tożsamości żydowskiej w literaturze, ale w przypadku Szczecina opisywanego w tekstach literackich można o niej mówić jako o bardzo charakterystycznej cesze "miasta po(st)granicznego", stanowiącego miejsce wyłączone, na które składa się wyparta pamięć obecności żydowskiej i niemieckiej oraz nigdy w pełni nie przyswojona tożsamość polska.
\end{abstract}

Abstract: Paweł Wolski, (POST)BORDER URBAN NARRATIONS. LITERARY RE-CONSTRUCTIONS OF JEWISH SZCZECIN. "PORÓWNANIA" 11, 2012, Vol. XI, pp. 291-300, ISSN 1733165X. Jewish identity of the post-war Szczecin may be considered almost symbolic for the state

${ }^{1}$ Projekt został sfinansowany ze środków Narodowego Centrum Nauki przyznanych na podstawie decyzji numer DEC-2011/03/D/HS2/02781.

2 Correspondence Address: wolski@op.pl 
of the Jewish community in Poland: it is marked by a noticeable absence. However, the absence in the case of Szczecin, if reflected upon on the narrative level, goes beyond that tragic, yet clichéd paradox. Jewish Szczecin as a literary reality exists as a "signifiant" of a Jewish town described by means of other urban symbols (Warsaw, Kielce etc.).The article Post-border Urban Narratives presents the ephemeral nature of the literary Szczecin on the example of various narratives by Anna Frajlich, Inga Iwasiów, Alan Sasinowski and focuses on a text by Taube Kron, who describes Szczecin reaching for the symbolic "lieux de memoire" of the Jewish post-war history: Warsaw ghetto, Kielce in the time of pogroms or Lwów as Eastern Europe's Jewish urban center. In conclusion, it is argued that the "double absence" (of the Jewish and urban identification) can be considered emblematic for the Polish post-war Jewish memory in general, but in the case of the literary Szczecin, presents a particular state of a post-border town: a crossover of a lost/exiled Jewish and German presence and of a never fully acknowledged Polish identity.

Pisząc o geopoetyce, urban studies i zwrocie topograficznym, Elżbieta Rybicka co najmniej dwukrotnie odnosi się do pisarstwa Ingi Iwasiów. Nigdy jednak przy tej okazji nie wymienia Szczecina. Być może dlatego, że, zdaniem badaczki, miasto we współczesnej literaturze to nie

bezproblematyczne miejsce czasów przednowoczesnych, nawet gdy pojawiają się tak liczne miasta konkretne, to nie są to Gdańsk, Wrocław Warszawa, Kraków, ale raczej „Gdańsk”, ,Wrocław”, ,Warszawa”, ,Kraków”3

- to znaczy nie interesuje jej - geopoetyki i Rybickiej - Gdańsk, Wrocław itd., ale Gdańsk Güntera Grassa, Wrocław Marka Krajewskiego, Warszawa Marka Rymkiewicza. I - wreszcie - Szczecin Ingi Iwasiów, w którym to I. Iwasiów i jej konstrukcja miasta jest ważniejsza niż miasto samo. Może więc właśnie dlatego, gdy $\mathrm{w}$ artykule Zwrot topograficzny w badaniach literackich pisze o "ujarzmianiu kobiecego ciała w uniwersyteckim budynku dawnych koszarów" ${ }^{4}$ albo w Modernizowaniu miasta o palimpsestowości współczesnej przestrzeni miejskiej w prozie kobiecej, nie uznaje za stosowne wymieniać nazwy miasta, o które chodzi (bo że nie wymienia nazwiska autorki, to prawdopodobnie wynika ze swoistego tacit agrement: ślepy bard to Homer, znak to Prince, uniwersytet, gender i koszary to Iwasiów).

Może jednak przyczyna jest inna. Albo równoległa, dopełniająca wobec tamtej. Bo pewnie nieprzypadkowo Rybicka, gdy pisze - nie pisząc - o Szczecinie, odnosi się akurat do pisarstwa Iwasiów, a nie, na przykład, do Heleny Raszki albo nieco

${ }^{3}$ E. Rybicka, Modernizowanie miasta Zarys problematyki urbanistycznej w nowoczesnej literaturze polskiej. Kraków 2003, s. 320.

${ }^{4}$ E. Rybicka, Zwrot topograficzny w badaniach literackich, w: Kulturowa teoria literatury 2. Poetyki, problematyki, interpretacje. Red. T. Walas, R. Nycz. Kraków 2012, s. 337. 
na siłę inkorporowanej w poczet pisarek szczecińskich (lub przynajmniej pomorskich) Joanny Kulmowej. W Modernizowaniu miasta wymienia jej dawniejszy zbiór opowiadań Miasto - ja - miasto, ale już tekst o najnowszych zwrotach w badaniu miejskości można czytać z perspektywy jej ostatniej dylogii (zmierzającej do trylogii), czyli Bambino i Ku słońcu. A są to nie tylko książki o Szczecinie, bo na przykład Ku słońcu, jak na powieść z wątkami akademickimi przystało, jest także książką o Szczecinie w literaturze i - co ciekawsze - w literaturoznawstwie. Pojawia się w niej bowiem motyw profesorki Małgorzaty i jej doktoranta Marka, którzy badają historię Hildegardy, znanej zamkniętemu gronu antykwariuszy i pasjonatów jako

córka grafa, wykształcona i nieprzeciętna, autorka wierszy, rozważań modlitewnych, dziennika, trzykrotna mężatka i mniszka, oskarżana dwukrotnie o czary, w końcu zamknięta w klasztorze, data śmierci nieznana ${ }^{5}$.

Mówiąc krótko - pisarki będącej modelową figurą emancypacyjno-genderowej aporii, do tego jeszcze angażującej niezbędnego na tę okoliczność Foucaulta i przydatnego Norę, bo uwikłanej w dyskurs politycznie warunkowanej topochronii. Cytuję:

Antykwariusz zaczął szukać dowodów na istnienie osiemnastowiecznej pisarki. Wzmianek o niej nie znalazł w niemieckich słownikach, co było dziwne. XVIII wiek nie tonął przecież w mroku niewiedzy, Niemcy cenili swoją spuściznę. Przyjaciółka germanistka postawiła wówczas hipotezę, że Stettin był dla Niemców prowincją i po prostu nie okazywali zainteresowania szalonymi pisarkami, w dodatku niewiadomego pochodzenia - w Hildegardzie płynęła krew wszystkich władców i wyrobników tej ziemi, a więc prusko-szwedzko-rosyjsko-francuska, nie bez komponentu słowiańskiego, załóżmy. W końcu utrwalana w szkole i propagandzie wiedza o prasłowiańskim rodowodzie tej ziemi musiała mieć jakieś podstawy. Może ona była, załóżmy, Polką?.

Hildegarda skupia więc $\mathrm{w}$ sobie splot wszystkich topograficznych wątków pamięci Stettina-Szczecina, czy może raczej: ich współczesnej projekcji, bo fakt umieszczania jej życia w zamierzchłym osiemnastym wieku nie ma wielkiego znaczenia (co stanie się jeszcze oczywistsze, gdy pod koniec krótko rozwinę jej „literaturoznawczy" wątek). Hildegarda może i jest lokowana w wieku XVIII, ale w strukturze narracyjnej Ku słońcu jest postacią jak najbardziej współczesną, łączącą to, co w pamięci miasta nie historyczne, ale aktualnie jako historyczne tworzone. Jeśli tak, to czegoś w jej sylwetce brakuje. Czego? Powtórzmy domniemania antykwariusza i germanistki, pary paralelnej wobec Małgorzaty i jej doktorantakochanka: w Hildegardzie płynęła krew „prusko-szwedzko-rosyjsko-francuska”. „Może ona była, załóżmy, Polką?”.

\footnotetext{
${ }^{5}$ I. Iwasiów, Ku stońcu. Warszawa 2010, s. 221.

${ }^{6}$ Ibidem.
} 
Otóż brakuje oczywiście w tej mieszance krwi władców i wyrobników szczecińskiej ziemi komponenty żydowskiej. Ale to nie tak, rzecz jasna, że opowieści snutej w Ku słońcu czegoś brakuje w sensie historycznym, bo według annałów Żydzi w Szczecinie na dobre osiedlili się dopiero w wieku XIX. Zresztą gdy piszę „brakuje”, nie mam na myśli w ogóle jakiegokolwiek defektu narracyjnego. Mam na myśli raczej brak znaczący: nie jest przypadkowym fakt, że to właśnie Hildegarda, obejmująca wszystkie poza jednym elementy historycznej identyfikacji, jest w narracji Iwasiów figurą mającą uspójnić opowieść o mieście (i jego najnowszej pamięci, bo nakłada się na nią historia Solidarności, lustracji i innych wątków związanych z ojcem Marka). Szczecin jest bowiem (to teza mojego krótkiego przyczynku do tematu) miastem rekonstrukcji i nieobecności, albo raczej: rekonstrukcji nieobecności.

To, zdawałoby się, dość łatwa metafora. Nie-miejsce, szczególnie nie-miasto i nie-sztetl żydowskie to powszechny koncept powojennego, utrwalonego w wierszu Antoniego Słonimskiego braku („Nie masz już, nie masz w Polsce żydowskich miasteczek"). Spieszę więc wyjaśnić, że nie o brak Żydów w moim tekście chodzi, ale o brakującą tożsamość żydowską jako element narracyjnego budowania miasta.

Tożsamość żydowska nie jest jedyną, która w ten negatywny sposób buduje identyfikację Szczecina. Tak właśnie tworzony jest, choć z innych powodów, również i niemiecki, i polski Szczecin. Tym ostatnim, jak donosi Rybicka, zajęła się już z powodzeniem Magdalena Mikołajczak w tekście "Szli na Zachód osadnicy..."7. Również Szczecin niemiecki został nieźle opisany, i to na różne sposoby. Jednym $\mathrm{z}$ bardziej intrygujących i w pewnym sensie uprzedzającym moją nieodkrywczą w związku z tym tezę są prace Erazma Kuźmy, który pisząc o tworzeniu mitu Orientu w literaturze XIX i XX wieku' ${ }^{8}$, pisał w pewnym sensie o tworzeniu pamięci Ziem „Od”-zyskanych. Jeśli więc tę tezę proponuję, to dlatego, że chcę do tamtych rozważań dodać być może wyjaśniający coś wątek odzyskiwania i tracenia wątku pamięci żydowskiej.

Żydowski Szczecin w literaturze istnieje tylko przyczynkowo, i to niezależnie od językowych czy geograficznych podziałów tej literatury. U polsko-niemieckiej pisarki Britty Wuttke pamięć Żydów jest paralelą losów Niemców na powojennym Pomorzu Zachodnim, wprowadzaną krótkim „nur für”, łączonym z miejscami kiedyś niechętnie dostępnymi, teraz nostalgicznie niedostępnymi ${ }^{9}$ (co zresztą przy innej okazji warto poddać diagnozom urban studies spod znaku bell hooks ${ }^{10}$, tzn.

${ }^{7}$ M. Mikołajczak, „Szli na Zachód osadnicy...". Rola metaforyki przestrzennej w tworzeniu mitologii Ziemi Lubuskiej (maszynopis referatu wygłoszonego na konferencji Przestrzeń jako kategoria poetyki, Białystok 2011). Za: E. Rybicka, Zwrot..., op. cit., s. 337.

${ }^{8}$ E. Kuźma, Mit Orientu i kultury Zachodu w literaturze XIX i XX wieku. Szczecin 1980.

${ }^{9}$ B. Wuttke, Homunculus z tryptyku. Przedmowę napisał Witold Nawrocki. Poznań 1980.

10 bell hooks, Margines jako miejsce radykalnego otwarcia. Przeł E. Domańska. „Literatura na Świecie" 2008, nr 1-2. 
walki pamięci politycznej z konserwatywną nostalgią). Co prawda akurat B. Wuttke mniej pisze o Szczecinie niż o jej rodzinnym Świnoujściu, za to w pamięć topograficzną odtwarzaną już bezpośrednio z perspektywy Szczecina wpisuje się bezpośrednio Die Mittagsfrau Julii Franck ${ }^{11}$. Jest to historia dochodzenia i odchodzenia od nazizmu, ale przede wszystkim: opowieść o miastach, o ich życiu zmienianym przez wojnę i o przekształcaniu się architektonicznych symboli jak Alexanderplatz w Berlinie czy Hakenterrasse w Szczecinie. Narratorka, żona nazistowskiego oficjela przeniesionego z Berlina do Stettina, w końcowych scenach gubi w lasku synka. Szukając go, napotyka zostawiony na bocznicy wagon kolejowy, zaskakujący ją dobiegającym $\mathrm{z}$ wewnątrz przerażającym zapachem, nieludzkimi, choć cichymi odgłosami i owiany niewyjaśnialną aurą. Ten jednostronicowy opis niesamowitości Zagłady w ponad czterystustronicowej książce o nazizmie, Zagłady nie tyle oglądanej oczyma Niemki, co zbiorowej o niej pamięci rekonstruowanej z perspektywy życia społecznego (w tej powieści jest to życie miejskie: w pierwszej części to przedwojenny, roztańczony Berlin, w drugiej wojenny, monumentalny i chylący się ku upadkowi Stettin), spychającego Holocaust w obszary pograniczne (pograniczny jest sam Szczecin jak i - z perspektywy miasta - leśna, podmiejska bocznica), jest genialną impresją mogącą symbolizować rekonstrukcję żydowskiego Szczecina w literaturze: takiego, który istnieje jako niechętne odtwarzanie, jako pamięć niechciana w każdym z jej skomplikowanych historycznych wątków; by wymienić te najnowsze: niemieckim, żydowskim i polskim. I to właśnie środkowy z nich sygnuje ową nieobecność najdoskonalej.

Sytuacja, jaką opisałem, nie jest więc tylko sprawą nieprzepracowanej traumy, także w kategoriach narracyjnych. Gdyby tak było, przypadek Szczecina nie byłby w żaden sposób charakterystyczny na tle pamięci innych miast i pamięci powojennej w ogóle. Elżbieta Janicka tak chce widzieć Warszawę w Festung Warschau ${ }^{12}$, a Władysław Panas, uciekając się do figury chiazmu albo metafory rany, tak właśnie, jako „obecną nieobecność”, chciał przecież opisywać tożsamość żydowską, nie tylko w powiązaniu z jej miejskością i niekoniecznie w ścisłym związku ze świadomością poholocaustową ${ }^{13}$. W narracjach tworzących powojenny Szczecin charakterystyczne jest jednak to, że nie ma w nich miasta innego niż tworzonego przez pryzmat tymczasowości: nieobecność nie jest tylko sprawą funkcjonalnej metafory (choć jest nią także), ale faktem narracyjnym. Szczecin jest nieobecny w szczecińskiej literaturze tak samo, jak nieobecna jest w nim szczecińska żydowskość. Jest to taka identyfikacja dzielnic, kamienic i ulic, która budowana jest na zasadzie negatywnych punktów odniesienia. Anna Frajlich wspominając w krót-

\footnotetext{
${ }^{11}$ J. Franck, Die Mittagsfrau. Frankfurt am Main 2007.

12 E. Janicka, Festung Warschau. Raport z oblężonego miasta. Warszawa 2011.

${ }^{13}$ W. Panas, Pismo i rana. Szkice o problematyce żydowskiej w literaturze polskiej. Lublin 1997 (m.in. w eseju Zamach pióra).
} 
kim opowiadaniu swoją szczecińską przeszłość w części zatytułowanej „Żydzi” (inne tytuły to np. „Szkoła”, „Kultura, sztuka, pisanie”, ale też bardziej znaczące w interesującym mnie kontekście: „Wszyscy byliśmy rozbitkami” i - jeszcze bardziej - „Niemcy”), pisze właściwie o tym, że Szczecin dla niej to miasto, w którym „z instytucjami żydowskimi miała bardzo mały kontakt"14. Pisarka wyraźnie podkreśla, że żydowski Szczecin oznacza dla niej mieszkanie w dzielnicy nieżydowskiej (Niebuszewo, zwane z powodu osiedlania się w nim dużej liczby Żydów przybyłych ze wschodu - często tylko tranzytem dalej na zachód - Lejbuszewem, w ogóle pojawia się w literaturze o żydowskim Szczecinie tylko przyczynkowo, częściej w narracjach historycznych niż literackich). Żydowskość tego miasta u A. Frajlich jest właściwie opisywana, paradoksalnie, za pośrednictwem jej debiutu pisarskiego w warszawskiej „Fołks-Sztyme” albo poprzez spotkanie z łódzkim przyjezdnym teatrem żydowskim Idy Kamińskiej oraz występującym w nim Henrykiem Grynbergiem. Czyli: żydowski Szczecin to Łódź i Warszawa.

Żydowskość Szczecina - nieżydowskość żydowskiego Szczecina - oddaje też dobrze tytuł innej miniatury, tym razem autorstwa Katarzyny Weintraub: „Karp pożydowski". Szczecin jest bowiem równie pożydowski, jak i poniemiecki, tzn. od zawsze pożydowski i inherentnie poniemiecki, a przy tym wiecznie przedpolski. Autobiograficzne opowiadanie Taube Kron Droga do domu ${ }^{15}$ ukazuje to już w bardziej bezpośrednim związku z kłopotliwą topografią i topochronią tego miejsca.

Otóż Szczecin wyłaniający się z tego tekstu jest właśnie żydowskim Szczecinem pozbawionym i Szczecina i żydowskiego doświadczenia. Jedno i drugie - to jest miasto i żydowskość - jest w tekście zastępowane przez inne miasta: Lwów, Warszawę, Łódź i Kielce. Nie są to przy tym porównania do znanych z przeszłości struktur miejskich, porównania, w których nieoswojona przestrzeń opisywana jest przy pomocy znanych już motywów. To nie żydowski Szczecin przywołuje z pamięci inne miasto, czyli jest jak żydowski Lwów albo jak warszawskie getto. Odwrotnie: to właśnie zniszczone i właściwie nieznane narratorce warszawskie getto albo nie doświadczony pogrom kielecki potwierdzają realność miejsca, w którym się rzeczywiście znajduje. Oto przykłady.

\section{Przykład pierwszy: Szczecin jako Lwów}

Szczecin z narracji T. Kron poznajemy od strony architektonicznych i topograficznych szczegółów. Nie jest to jednak szczegółowy opis obejmujący całość znanego narratorce miasta, ale topograficzne wyimki i architektoniczne migawki.

14 A. Frajlich, Mój Szczecin? „Pogranicza” 2003, nr 4, s. 31.

15 T. Kron, Droga do domu (fragment większej catości). „Pogranicza” 2003, nr 4. W dalszej części tekstu podaję numery stron $\mathrm{z}$ tej publikacji bezpośrednio $\mathrm{w}$ tekście zaraz po cytacie lub odniesieniu. 
A przy tym nie jest to też zburzone, przerażające miasto, ale miasto, które rodzinę narratorki przyjęło względnie dobrze: „Nie byliśmy do tego urzędu [do Państwowego Urzędu Repatriacyjnego - P.W.] negatywnie ustosunkowani: była to dla nas pomoc zasadnicza i jedyna” i dalej: „Odnaleźliśmy wskazane [przez PUR - P.W.] mieszkanie - to, co tam odkryliśmy, nie było dla nas nawet takie straszne. Wiadomo, wojna, gruzy na ulicach, gruzy w domu. Ulica Parkowa 35 (może 37? lub 33?)...” (11) itd. „Nie byliśmy negatywnie ustosunkowani” i „nie było nawet takie straszne" to, można chyba tak sądzić, wyrazy skrajnej obojętności, szczególnie jeśli pamiętać, że to opis uczuć po długiej podróży w fatalnych warunkach w nieznane i po osiedleniu się w od teraz własnym domu (w słowach „nasze mieszkanie” "nasze" jest graficznie wyróżnione). Szczecin ani przeraża, ani cieszy; po prostu jest. Ten opis zmienia się dopiero wtedy, gdy narratorka spotyka się z niejakim Borkowiczem, który dzięki zarekomendowaniu jej przez znajomego ze Wschodu (opisywanego z odrazą jako wymachujący pistoletem i popisujący się zamożnością i układami beneficjent reżimu) angażuje jej bezrobotnego męża do pracy i wręcza jej uprawnienia do zapomogi. Różnica między oboma oficjelami - rekomendującym i udzielającym pomocy - jest taka, że pierwszy jest charakteryzowany, jak wspomniałem, jako znajomy ze Wschodu, powielający "zwyczaje z Rosji”, o drugim zaś mówi z sympatią, że to: „rodowity lwowiak, że to stary komunista, taki co swoje za kratami przesiedział, że [to zdaje się dość ważne] w nazwisku zmienił tylko drugą literę - «e» na «o»" (13). Co jednak jeszcze ważniejsze dopiero od momentu kontaktu z tym drugim, lwowiakiem i Żydem - w tej właśnie kolejności - opis Szczecina staje się mniej obojętny, to właśnie poprzez opis owego lwowiaka poznajemy robiące na narratorce wrażenie okolice Szczecina: urzędowe Jasne Błonia, handlowy plac Grunwaldzki. Szczecin, mimo nazywania go konkretnymi detalami topograficznymi (przypominam charakterystyczne próby przypomnienia sobie konkretnego numeru domu - zresztą żaden z tych numerów dziś nie istnieje, prawdopodobnie nie istniał też pięćdziesiąt lat temu), Szczecin istnieje jako Lwów, który zresztą też jest ważny o tyle, o ile jest żydowski.

\section{Przykład drugi: Szczecin jako Kielce}

Sytuacja Żydów w powojennym Szczecinie nie była, jeśli wierzyć narracjom takim jak tu cytowana, odmienna od ich sytuacji w innych miastach. Motywacje nierzadkiej wrogości wobec nich mogły być wprawdzie inne, niż te, które opisuje Gross ${ }^{16}$, bo majątki zajmowane przez osiedleńców należały raczej do Niemców niż Żydów, ale bezpośrednia przyczyna agresji bywała podobna. Oto opis Kron:

${ }^{16}$ Między innymi w Strachu (J. T. Gross, Strach. Antysemityzm w Polsce tuż po wojnie. Historia moralnej zapaści. Kraków 2008). 
„pewnego dnia usłyszałam krzyk, dobiegłam do frontowego okna i oto na ulicypodwórku jakaś rozczochrana kobieta biegnie lamentując 'Gdzie moje dziecko, wszystkie rude parchy się bawią, a gdzie moje dziecko? Gdzie moje dziecko? Na macę zabrali...” (16). A oto pointa: „Gdyby nie Kielce i wszystko inne, co nas ominęło, plus to, co nas nie ominęło - mogłabym dziś zapisać to wydarzenie między legendy. Niestety!!!" (17).

$\mathrm{Na}$ pozór jest to po prostu umieszczanie niejasnego wówczas wydarzenia w szerszym i po latach dobrze metonimizującym całość kontekście - w kontekście kieleckiego pogromu jako najlepiej znanego wydarzenia $\mathrm{z}$ niechlubnej historii relacji polsko-żydowskich. Jeśli jednak czytać ten fragment z perspektywy poetyki miasta, mając w pamięci obcość, albo raczej: obojętność wobec Szczecina zmieniającą się w emocjonalny opis dopiero wówczas, gdy przywoływane jest inne miasto, takie jak Lwów, czy tutaj: Kielce, (tym wyraźniej emocjonalny, że narratorka opatruje to "kieleckie” doświadczenie trzema wykrzyknikami) i to w powiązaniu z miast tych historią żydowską, sprawia, że trudno nie czytać tego fragmentu jako aporii, przez którą wyłania się nie-miejsce Szczecina i jego nie-żydowskość. Bo dopiero historia innego miejsca jest w stanie zaktywizować pamięć żydowskiego miasta na Pomorzu Zachodnim.

\section{Przykład trzeci: Szczecin jako Warszawa}

Narracyjne climax opowieści o żydowskim Szczecinie przypada w podwójnie ważnym fabularnie miejscu: po pierwsze, w przededniu narodzin dziecka, pierwszego $\mathrm{w}$ rodzinie narratorki szczecinianina, po drugie, $\mathrm{w}$ miejscu przywołania jednego z najwyraźniejszych symboli powojennej identyfikacji żydowskiej, a przynajmniej tej, która obiera za kontekst Holocaust lub drugą wojnę światową. Otóż w ósmym miesiącu ciąży narratorka decyduje się odpocząć odwiedzając Łódź i, przede wszystkim, Warszawę. Warszawa dla narratorki to zrównane z ziemią getto, które jest pierwszym i jedynym $\mathrm{w}$ całym tekście fragmentem podającym w sposób skoordynowany (w odróżnieniu od szczecińskich migawek), a przy tym skondensowany jakiekolwiek topograficzne szczegóły. Warszawa - i to paradoksalnie: Warszawa zniszczona, zrównana z ziemią, czyli właściwie nieistniejąca zostaje umieszczona $\mathrm{w}$ narracyjnym środku opowieści o wrastaniu w Szczecin (przypominam: po tym epizodzie następuje opis narodzin dziecka). Oto fragment: Szliśmy właśnie ulicą Gęsią, jedną z pobrzeżnych tego obszaru, gdzie potem pomnik, nowa Miła, nowa Niska, nowa Smocza i inne" (19). W tym jednym warszawskim akapicie - który wcale w tym miejscu się nie kończy - jest mniej więcej tyle samo nazw ulic, co na pozostałych kilku stronach akcji dziejącej się w Szczecinie.

Pomijam kilka innych ważnych okoliczności interpretacyjnych miejskiego czytania tekstu Kron, takich jak na przykład obecność w tej narracji Niemców. Nie 
rozwijam tego wątku, wspomnę tylko, że symbolizują oni w opowieści Kron ambiwalentną obcość, obcość niechcianą przez innych mieszkańców Szczecina i akceptowaną - choć z ledwie tajoną niechęcią - przez narratorkę. Czyli, chciałoby się rzec: także Niemcy, choć w inny sposób, symbolizują taką szczecińskość, o jakiej tu mowa. Niemiecko-żydowsko-polska pamięć miasta w szczecińskiej literaturze cechuje się bowiem właśnie taką niechętną próbą jego oswojenia, próbą zawsze niedokończoną. Próbą, która rozciąga się od niemieckojęzycznych napisów na studzienkach tropionych w tekstach Artura Daniela Liskowackiego po prozę Alana Sasinowskiego, który w Rupieciu opisuje na przykład Szczecin z perspektywy obserwatora niemieckich turystów kolonizujących szczecińskie hipermarkety (notabene niemieccy turyści zwiedzający polskie i "pożydowskie” miasta dojechali też do literackiej Warszawy: Igor Ostachowicz w Nocy żywych Żydów umieszcza ich $\mathrm{w}$ fantastycznej wizji twardo- i sztuczno zębnych bojówek biorących stronę neonazistów $\mathrm{w}$ walce na pamięć powstania warszawskiego z powstaniem w get$\mathrm{cie}^{17}$ ). Hipermarketowe wcielenie flâneura jako uczestnika życia centrów handlowych we współczesnym mieście nie jest, oczywiście, tylko sprawą szczecińską, ale częścią doświadczenia współczesności ponad podziałami grodzkimi, tropionego przez Anne Friedberg od Pasaży Waltera Benjamina po teorię ery post-zakupów Faith Popcorn ${ }^{18}$. Jednak u Sasinowskiego ta tymczasowość zostaje wzmocniona postkolonialnym kontekstem polsko-niemieckiej granicy. Jest tak i u Ingi Iwasiów, która w Ku Słońcu, podobnie jak Britta Wuttke, przywołuje dodatkowo ślady żydowskiego albo może raczej antyżydowskiego miasta za pośrednictwem aluzyjnego „nur für”, sygnującego powojenne kolonizowanie przestrzeni należących do innych. Jest tak wreszcie $\mathrm{w}$ wielu innych narracjach, które starają się scalić tę postgraniczną tożsamość w sposób, który świetnie zdiagnozowała (choć w nieco odmiennym kontekście) Dorota Kołodziejczyk: „umiejscowienie podmiotu, jego pozycyjność, jego wewnętrzne napięcie pomiędzy ruchem (migracją, podróżą, wykorzenieniem) ukazuje tożsamość jako heterotopię: miejsce, gdzie spotyka się kilka różnych, często niekompatybilnych lub wzajemnie obcych przestrzeni. Wykorzystanie definicji heterotopii z kategorii ściśle przestrzennych na tożsamościowe ma rewolucyjny efekt - ukazuje ona niewystarczalność dychotomii ja/inny, koniecznej dla celów analitycznych w konstruowaniu spójnej tożsamości, lecz wyrzucającej niebezpieczeństwo kryzysu i niezgodności wewnętrznej bezpośrednio na zewnątrz"19. Cytuję Kołodziejczyk znów za Rybicką, od której zacząłem, i która w tym kontekście używa pojęcia nie-miejsca. To chyba dobry moment, żeby do-

17 I. Ostachowicz, Noc żywych Żydów. Warszawa 2012.

18 A. Friedberg, „....więc jestem”. Kupujący-widz i przeistoczenie poprzez zakupy. Przeł. B. Brzozowska, w: Miasto w sztuce - sztuka miasta. Red. E. Rewers. Kraków 2010.

${ }^{19}$ D. Kołodziejczyk, Trawersem przez glob: studia postkolonialne i teoria globalizacji. "Er(r)go" 2004, nr 1, s. 21. 
powiedzieć historię Hildegardy w narracji Iwasiów, autorki przywoływanej przez Rybicką być może właśnie jako pisarki post-granicznej, dobrze ukazującej funkcjonowanie narracji o żydowskim nieistniejącym mieście (jeśli moja nadinterpretacja jej tekstów teoretyczno-interpretacyjnych nie przekracza granic zdrowego rozsądku). Otóż historia Hildegardy, szczecińskiej pisarki łączącej w sobie wszystkie tożsamości poza żydowską, kończy się w Ku słońcu tak:

Marek wpada po powrocie do domu w ramiona Małgorzaty. Kochają się krótko, bez słów, a potem ona, leżąc w pozycji embrionu, mówi:

- Nie ma Hildegardy.

- Co takiego? Jak nie ma?

- Tak, nie ma. Przeczytałam jeszcze raz wszystko. Moim zdaniem nie istniała taka pisarka. Powołali ją do życia ci z klubu [Małgorzata ma na myśli klub czytelnikówamatorów w przedwojennym Stettinie]. Scalili jakąś literacką legendę, parę legend. Dobrali do nich niemające przydziału tomiki, rozproszone teksty. Następni nie czytali już niczego dokładnie. Nie mogli, nie mieli możliwości i kompetencji. A my, a ja szkoda słów. Nie ściągałam pierwodruków, zaufałam innym. Teraz widzę, że nie da się obronić faktu istnienia Hildegardy ${ }^{20}$.

W tym fragmencie chciałbym widzieć genialną intuicję Rybickiej, używającej pisarstwo Iwasiów - a za jej pośrednictwem Szczecin - do opisu szczególnego statusu nie-miejsc i heterotopii. Nieistniejąca szczecińskość Hildegardy jest symbolem re-konstrukcji tego miasta w literaturze. Większość szczecińskich mitów to produkty odtwarzane, niczym szczecińska starówka istniejąca od kilku zaledwie dekad. Szczecińska żydowskość opowiadana w literaturze to jeden z nich, zawierający w sobie, jak biografia Hildegardy, wpisany w swoją istotę narracyjny brak.

${ }^{20}$ I. Iwasiów, op. cit., s. 287. 